\title{
Biomimetic lodofunctionalization of Aromatic and Heteroaromatic Compounds Catalyzed by Selenium Tetrachloride
}

\author{
Beatriz C. O. Rocha \\ Givago P. Perecim \\ Cristiano Raminelli* (i)
}

Instituto de Ciências Ambientais, Químicas e Farmacêuticas, Universidade Federal de São Paulo, Rua Prof. Artur Riedel, 275, Diadema, SP 09972-270, Brazil

raminelli@unifesp.br
Received: 17.10.2019

Accepted after revision: 29.10.2019

Published online: 19.11 .2019

DOI: 10.1055/s-0039-1690337; Art ID: so-2019-d0031-I

License terms: $c(A)$

(c) 2019. The Author(s). This is an open access article published by Thieme under the terms of the Creative Commons Attribution-NonDerivative-NonCommercial-License, permitting copying and reproduction so long as the original work is given appropriate credit. Contents may not be used for commercial purposes or adapted, remixed, transformed or built upon. (https://creativecommons.org/licenses/by-nc-nd/4.0/)

Abstract A biomimetic iodofunctionalization of aromatic and heteroaromatic compounds has been developed using Nal as a source of iodine and $30 \% \mathrm{H}_{2} \mathrm{O}_{2}$ as a mild oxidant, as well as $\mathrm{SeCl}_{4}$ as a commercially available catalyst in water without a co-solvent. The method affords iodinated compounds in isolated yields of 37 to $99 \%$. The catalytic system has potential for the bromination of aromatic substrates.

Key words biomimetic synthesis, iodofunctionalization, selenium catalysis, iodination, aqueous reaction

Iodofunctionalized molecules are versatile building blocks in preparative organic chemistry with application, for example, in cross-coupling reactions, ${ }^{1}$ as well as in iodine-lithium $^{2}$ and iodine-magnesium ${ }^{3}$ exchange processes. These transformations can be considered valuable methods for the formation of carbon-carbon and carbon-heteroatom bonds, ${ }^{1-3}$ which are useful in the total syntheses of natural products ${ }^{4}$ and in the production of polymers with varied properties. ${ }^{5}$ Furthermore, several organic compounds containing iodine are biologically active substances ${ }^{6}$ or have been employed in targeted molecular radiotherapy ${ }^{7}$ and as contrast media for diagnostic imaging. ${ }^{8}$ Therefore, a considerable number of approaches for the iodofunctionalization of organic molecules has been developed. ${ }^{9-12}$ Among them, the one-pot diazotization-iodination of aromatic and heteroaromatic amines ${ }^{10}$ and the electrophilic iodination of aromatic and heteroaromatic substrates ${ }^{11}$ can be considered well-established strategies to prepare iodinated

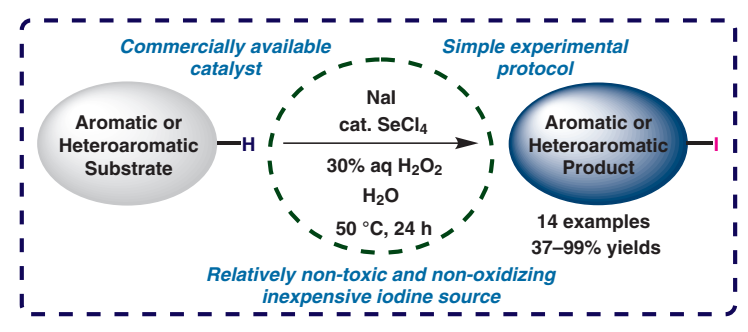

aromatic and heteroaromatic compounds. Although diazotization-iodination reactions have limitations related to the use of starting materials containing amino groups, and electrophilic iodination reactions employ relatively toxic, oxidizing, and expensive halogenating reagents, both approaches can be considered useful in organic synthesis. ${ }^{10,11}$ To circumvent the disadvantages, Detty and co-workers have explored halogenation reactions involving halide salts as the sources of halogen and aqueous hydrogen peroxide as a mild oxidizing, and the reactions have been successfully catalyzed by chalcogen-containing compounds. ${ }^{12}$ In these transformations the organochalcogens employed as catalysts mimic haloperoxidase enzymes ${ }^{13}$ allowing environmentally friendly halogenations of organic substrates. ${ }^{12,14}$ Nonetheless, to our knowledge, only one study that provides a general method for the iodination of organic substrates employing $\mathrm{NaI}$ and $\mathrm{H}_{2} \mathrm{O}_{2}$ catalyzed by a water-soluble organotelluride has been reported. ${ }^{12 \mathrm{~d}}$ Only low catalyst loadings were required for the iodinations described; however, the water-soluble catalyst had to be prepared in four steps from 4- $N, N$-bis(carboethoxymehyl)aniline. ${ }^{12 \mathrm{~d}}$ In this context, having in mind the demand for iodinated aromatic and heteroaromatic compounds in synthetic organic chemistry, along with the potential applications of iodinated compounds in medicine, we have developed a novel method for the biomimetic iodination of aromatic and heteroaromatic compounds employing $\mathrm{NaI}$ as iodine source, $30 \%$ $\mathrm{H}_{2} \mathrm{O}_{2}$ as oxidant, and $\mathrm{SeCl}_{4}$ as catalyst, in water without a co-solvent, affording iodinated aromatic and heteroaromatic compounds in good isolated yields. Through this methodology we can avoid the limitations related to the use of starting materials containing amino groups, as well as oxidizing, and expensive halogenating reagents, with the convenience of employing $\mathrm{SeCl}_{4}$ as a commercially available catalyst. 
Initially, the reactions were carried out employing 1-(4hydroxyphenyl)ethanone (1a), $\mathrm{NaI}$ (2.5 equiv), 30\% aqueous $\mathrm{H}_{2} \mathrm{O}_{2}$ ( 0 to 5 equiv), the appropriate catalyst ( 0 to $20 \mathrm{~mol} \%$ ), and distilled water. The mixtures were stirred at room temperature or $50{ }^{\circ} \mathrm{C}$ for $24 \mathrm{~h}$ or $48 \mathrm{~h}$ (Table 1, entries $1-11$; Procedure A). The use of selenium and tellurium powder was evaluated, envisioning the in situ formation of the corresponding selenium(IV) and tellurium(IV) species, which could catalyze the reaction. However, in both experiments, 1-(4-hydroxy-3-iodophenyl)ethanone (3) was obtained in yields lower than 5\% (entries 1 and 2). When the transformation was performed in the presence of $\mathrm{SeCl}_{4}$ ( $5 \mathrm{~mol} \%$ ) or $\mathrm{TeCl}_{4}$ ( $5 \mathrm{~mol} \%$ ), we obtained 3 in yields of $20 \%$ and $21 \%$, respectively (entries 3 and 4). In the absence of catalyst, compound 3 was isolated in 10\% yield (entry 5). At this point, we decided to continue the experiments using $\mathrm{SeCl}_{4}$ as catalyst based on the cost-benefit ratio. The use of distilled water instead of a buffer solution was reasonable because the reactions presented initial and final $\mathrm{pH}$ values of 6 (entries 1-5). Allowing the reaction to proceed in the absence of $30 \% \mathrm{H}_{2} \mathrm{O}_{2}$, we did not observe the formation of 1-(4-hydroxy-3,5-diiodophenyl)ethanone (2a) or 3. In addition, both initial and final $\mathrm{pH}$ values were $\mathrm{pH} 4$ (entry 6). Increasing the catalyst loading to $20 \mathrm{~mol} \%$ and the reaction time to $48 \mathrm{~h}$, compounds $\mathbf{2 a}$ and $\mathbf{3}$ were obtained in yields of $38 \%$ and $23 \%$, respectively (entries $7-9$ ). Through an increase of reaction temperature, we isolated compounds 2a and 3 in yields of $37 \%$ and 26\%, respectively (entries 10 and 11). The reactions outlined in entries $7-10$ presented initial and final $\mathrm{pH}$ values of 6 . Interestingly, when the transformation was performed at $50{ }^{\circ} \mathrm{C}$ for $48 \mathrm{~h}$, the initial $\mathrm{pH}$ value was 6 and the final pH value was 1 (entry 11).

In an attempt to increase the yield of compound $\mathbf{2 a}$, the reactions were carried out by preparing a solution of $\mathbf{1 a}$ in distilled water, which was subjected to stirring at room temperature or $50{ }^{\circ} \mathrm{C}$. Then, a solution containing $\mathrm{SeCl}_{4}(20$ $\mathrm{mol} \%$ ) in distilled water was added. Afterwards, $2 \mathrm{M}$ aqueous solutions of $\mathrm{NaI}$ ( 2.5 equiv) and of $\mathrm{H}_{2} \mathrm{O}_{2}$ (5 equiv) were added alternately to the mixture in small aliquots (every 5 min over a period of $50 \mathrm{~min}$ ). The resulting mixture was

Table 1 Optimization of the Preparation of 4-Hydroxy-3,5-diiodoacetophenone (2a)

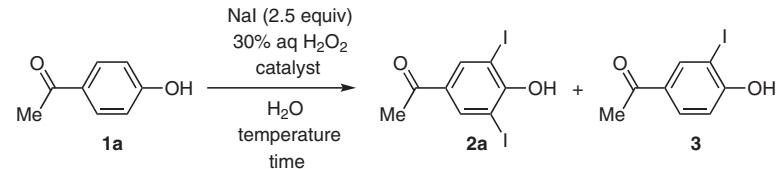

\begin{tabular}{|c|c|c|c|c|c|c|c|c|c|}
\hline \multirow[t]{2}{*}{ Entry } & \multirow[t]{2}{*}{ Procedure } & \multirow[t]{2}{*}{ Catalyst (mol\%) } & \multirow{2}{*}{$\begin{array}{l}30 \% \text { aq } \mathrm{H}_{2} \mathrm{O}_{2} \\
\text { (equiv) }\end{array}$} & \multirow[t]{2}{*}{ Temp $\left({ }^{\circ} \mathrm{C}\right)$} & \multirow[t]{2}{*}{ Time (h) } & \multicolumn{2}{|c|}{ Isolated yield (\%) } & \multicolumn{2}{|c|}{ pH values ${ }^{\mathrm{b}}$} \\
\hline & & & & & & $2 a$ & 3 & $\begin{array}{l}\text { Initial } \\
\left(\mathrm{pH}_{\mathrm{i}}\right)\end{array}$ & $\begin{array}{l}\text { Final } \\
\left(\mathrm{pH}_{\mathrm{f}}\right)\end{array}$ \\
\hline 1 & A & Se (5) & 5 & r.t. & 24 & 0 & $<5$ & 6 & 6 \\
\hline 2 & A & Te (5) & 5 & r.t. & 24 & 0 & $<5$ & 6 & 6 \\
\hline 3 & A & $\mathrm{SeCl}_{4}(5)$ & 5 & r.t. & 24 & 0 & 20 & 6 & 6 \\
\hline 4 & A & $\mathrm{TeCl}_{4}(5)$ & 5 & r.t. & 24 & 0 & 21 & 6 & 6 \\
\hline 5 & A & - & 5 & r.t. & 24 & 0 & 10 & 6 & 6 \\
\hline 6 & A & $\mathrm{SeCl}_{4}(5)$ & - & r.t. & 24 & 0 & 0 & 4 & 4 \\
\hline 7 & A & $\mathrm{SeCl}_{4}(10)$ & 5 & r.t. & 24 & 13 & 24 & 6 & 6 \\
\hline 8 & A & $\mathrm{SeCl}_{4}(20)$ & 5 & r.t. & 24 & 34 & 23 & 6 & 6 \\
\hline 9 & A & $\mathrm{SeCl}_{4}(20)$ & 5 & r.t. & 48 & 38 & 23 & 6 & 6 \\
\hline 10 & A & $\mathrm{SeCl}_{4}(20)$ & 5 & 50 & 24 & 37 & 26 & 6 & 6 \\
\hline 11 & A & $\mathrm{SeCl}_{4}(20)$ & 5 & 50 & 48 & 37 & 26 & 6 & 1 \\
\hline 12 & B & $\mathrm{SeCl}_{4}(20)$ & 5 & r.t. & 3 & 57 & $<5$ & 6 & 6 \\
\hline 13 & B & $\mathrm{SeCl}_{4}(20)$ & 5 & r.t. & 24 & 59 & 27 & 6 & 6 \\
\hline 14 & B & $\mathrm{SeCl}_{4}(20)$ & 5 & r.t. & 48 & 62 & 23 & 6 & 6 \\
\hline 15 & B & $\mathrm{SeCl}_{4}(20)$ & 5 & 50 & 24 & 62 & 26 & 6 & 6 \\
\hline 16 & B & $\mathrm{SeCl}_{4}(20)$ & 5 & 50 & 48 & 62 & 26 & 6 & 6 \\
\hline
\end{tabular}

a Reaction conditions: Procedure A: Compound 1a (2 mmol), Nal (5 mmol), catalyst, $\mathrm{H}_{2} \mathrm{O}(10 \mathrm{~mL})$, and $30 \% \mathrm{H}_{2} \mathrm{O}_{2}$ were maintained under stirring at the established temperature for the indicated time. Procedure $\mathrm{B}$ : To a solution of compound $\mathbf{1 a}\left(2 \mathrm{mmol}\right.$ in $2.5 \mathrm{~mL}$ of $\left.\mathrm{H}_{2} \mathrm{O}\right)$ under stirring at the indicated temperature was added a solution of $\mathrm{SeCl}_{4}\left(20 \mathrm{~mol} \%\right.$ in $5 \mathrm{~mL}$ of $\left.\mathrm{H}_{2} \mathrm{O}\right)$. Then, $2 \mathrm{M}$ aqueous solutions of $\mathrm{Nal}(5 \mathrm{mmol})$ and of $\mathrm{H}_{2} \mathrm{O}_{2}(10$ mmol) were added alternately in small aliquots (every $5 \mathrm{~min}$ over a period of $50 \mathrm{~min}$ ) and the resulting mixture was maintained under stirring at the established temperature for the indicated time.

${ }^{b} \mathrm{pH}_{\mathrm{i}}$ : initial $\mathrm{pH}$ value. $\mathrm{pH}_{\mathrm{f}}$ : final $\mathrm{pH}$ value. 
maintained under stirring at room temperature or $50{ }^{\circ} \mathrm{C}$ for 3 h, 24 h or 48 h (Table 1, entries 12-16; Procedure B). By employing Procedure B, at room temperature for $3 \mathrm{~h}, \mathbf{2 a}$ and 3 were isolated in yields of $57 \%$ and $<5 \%$, respectively (entry 12). On increasing the reaction time to $24 \mathrm{~h}$, and then to 48 h, compounds 2a and 3 were obtained in yields of 59-62\% and $23-27 \%$, respectively (entries 13 and 14 ). When the transformation was carried out at $50{ }^{\circ} \mathrm{C}$ for $24 \mathrm{~h}$ or $48 \mathrm{~h}$, the products 2a and $\mathbf{3}$ were isolated in similar yields of $62 \%$ and 26\%, respectively (entries 15 and 16). All reactions performed using Procedure B presented initial and final $\mathrm{pH}$ values of 6 (entries 12-16).

By employing the optimal conditions, i.e., the conditions that promoted the highest incorporation of iodine into 1a (Table 1, entry 15), we examined the scope of the transformation using phenols, anilines, and pyrazoles (1a-o) with electron-donating and electron-withdrawing groups (Table 2). ${ }^{15}$ By performing the reaction with phenolic compounds containing electron-withdrawing groups $(\mathbf{1 a}-\mathbf{c})$, we obtained the diiodinated products $\mathbf{2 a - c}$ in yields from $54 \%$ to $90 \%$ (entries $1-3$ ). The relatively low yield achieved for compound $\mathbf{2 b}$ (entry 2) was tentatively attributed to hydrolysis of the cyano group under the reaction conditions. However, no experimental evidence was obtained to support such a proposal. When 4-methylphenol (1d) was subjected to the diiodination reaction, 2,6-diiodo-4-methylphenol (2d) was isolated in 30\% yield (entry 4 ). The optimized reaction conditions did not work as expected for phenolic compounds containing electron-donating groups. By reducing the amounts of $\mathrm{NaI}$ and $\mathrm{H}_{2} \mathrm{O}_{2}$ to 1.25 equiv and 2.5 equiv, respectively, di- and monohalogenated phenols (1e-g) provided monoiodinated products $(\mathbf{2 e}-\mathbf{g})$ in yields from $57 \%$ to $76 \%$ (entries 5-7). Likewise, the anilines $\mathbf{1 h}-\mathbf{j}$ led to the formation of monoiodinated anilines $(\mathbf{2 h}-\mathbf{j})$ in isolated yields from $71 \%$ to $92 \%$ (entries $8-10$ ). When pyrazole (1k) was treated with $\mathrm{NaI}$ (1.25 equiv) and $\mathrm{H}_{2} \mathrm{O}_{2}$ ( 2.5 equiv) in the presence of $\mathrm{SeCl}_{4}$ (20 mol\%) using distilled water as solvent at $50{ }^{\circ} \mathrm{C}$ for $24 \mathrm{~h}, 4$-iodopyrazole (2k) was obtained in $25 \%$ yield (entry 11). In this reaction the starting material $\mathbf{1 k}$ was partially recovered and unidentified by-products were produced according to GC/MS analysis. By increasing the amounts of $\mathrm{NaI}$ (2.5 equiv), $\mathrm{H}_{2} \mathrm{O}_{2}$ (5 equiv), and $\mathrm{SeCl}_{4}$ (40 mol\%), we isolated 4-iodopyrazole (2k) in 37\% yield (entry 11). Treatment of 3,5-dimethylpyrazole (11) with $\mathrm{NaI}$ (1.25 equiv), $\mathrm{H}_{2} \mathrm{O}_{2}$ (2.5 equiv), and $\mathrm{SeCl}_{4}$ (20 mol\%) gave 4-iodo3,5-dimethylpyrazole (21) in 99\% yield (entry 12 ). Similarly, when 1-phenylpyrazole (1 $\mathbf{m}$ ) was subjected to the monoiodination reaction, 4-iodo-1-phenylpyrazole ( $2 \mathrm{~m})$ was isolated in $65 \%$ yield (entry 13 ). The iodination reaction of $3-$ amino-1,5-dimethylpyrazole (1n) provided the monoiodinated product $\mathbf{2 n}$ in $75 \%$ yield (entry 14 ). Conversely, when 1,5-dimethyl-1H-pyrazole-3-carboxylic acid (10) was subjected to the iodination reaction, 4-iodo-1,5-dimethyl- $1 \mathrm{H}$ pyrazole-3-carboxylic acid (2o) was not obtained, the starting material 10 was partially recovered, and unidentified substances were produced according to GC/MS analysis (entry 15).

Table 2 lodofunctionalization of Aromatic and Heteroaromatic Compounds $\mathbf{1}^{\text {a }}$

Entry Iromatic compound 1


Table 2 (continued)

\begin{tabular}{|c|c|c|c|}
\hline Entry & Aromatic compound 1 & lodinated aromatic compound 2 & Isolated yield (\%) \\
\hline 6 & & $-\mathrm{OH}$ & $57^{c}$ \\
\hline 7 & $1 \mathrm{~g}$ & $-\mathrm{OH}$ & $61^{c}$ \\
\hline 8 & $1 \mathrm{~h}$ & $\mathrm{Me}$ & $92^{c}$ \\
\hline 9 & $1 \mathrm{i} \mathrm{Me}$ & $\mathrm{NH}_{2}$ & $86^{c}$ \\
\hline 10 & & $\mathrm{Br}_{2 j}^{\prime}$ & $71^{c}$ \\
\hline 11 & $1 k$ & $2 k$ & $25^{c}(37)^{d}$ \\
\hline 12 & 11 & 2I & $99^{c}$ \\
\hline 13 & $\begin{array}{l}\mathrm{Ph} \\
1 \mathrm{~m}\end{array}$ & $\begin{array}{l}\mathrm{Ph} \\
\mathbf{2 m}\end{array}$ & $65^{c}$ \\
\hline 14 & $\begin{array}{l}\mathrm{Me} \\
1 \mathrm{n}\end{array}$ & $\begin{array}{l}\text { Me } \\
2 n\end{array}$ & $75^{c}$ \\
\hline 15 & $\begin{array}{l}\mathrm{Me} \\
10\end{array}$ & $\begin{array}{l}\mathrm{Me} \\
20\end{array}$ & $0^{c}$ \\
\hline
\end{tabular}

a Reaction conditions: To a solution of compound 1 ( $2 \mathrm{mmol}$ in $2.5 \mathrm{~mL}$ of $\mathrm{H}_{2} \mathrm{O}$ ) under stirring at $50{ }^{\circ} \mathrm{C}$ was added a solution of $\mathrm{SeCl}$ ( $20 \mathrm{~mol} \%$ in $5 \mathrm{~mL}$ of $\mathrm{H}_{2} \mathrm{O}$ ). Then, $2 \mathrm{M}$ aqueous solutions of $\mathrm{Nal}(5 \mathrm{mmol})$ and of $\mathrm{H}_{2} \mathrm{O}_{2}(10 \mathrm{mmol})$ were added alternately in small aliquots (every $5 \mathrm{~min}$ over a period of 50 min) and the mixture was maintained under stirring at $50{ }^{\circ} \mathrm{C}$ for $24 \mathrm{~h}$.

b Obtained using $20 \mathrm{~mol} \%$ of $\mathrm{SeO}_{2}$

' Obtained using $2.5 \mathrm{mmol}$ of $\mathrm{Nal}$ and $5 \mathrm{mmol}$ of $\mathrm{H}_{2} \mathrm{O}_{2}$

d Obtained using $40 \mathrm{~mol} \%$ of $\mathrm{SeCl}_{4}, 5 \mathrm{mmol}$ of $\mathrm{Nal}$, and $10 \mathrm{mmol}$ of $\mathrm{H}_{2} \mathrm{O}_{2}$.

A reasonable catalytic cycle to provide iodinated compounds 2 commences with hydrolysis of $\mathrm{SeCl}_{4}$ leading to $\mathrm{Se}(\mathrm{OH})_{4}$. After that, intermediates $\mathbf{A}$ and $\mathbf{B}$ are produced through ligand exchange reactions. Then, intermediate B undergoes reductive elimination, affording molecular iodine and $\mathrm{Se}(\mathrm{OH})_{2}$, which, in the presence of hydrogen 
peroxide, regenerates $\mathrm{Se}(\mathrm{OH})_{4} \cdot{ }^{12}$ The incorporation of iodine into aromatic and heteroaromatic compounds $\mathbf{1}$ takes place via electrophilic iodination (Scheme 1). ${ }^{11 e-g}$

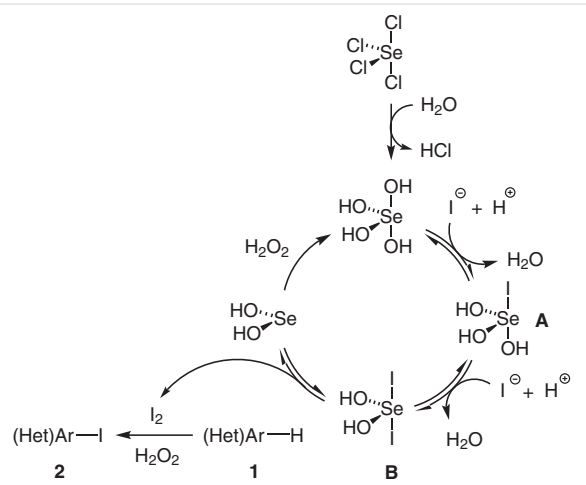

Scheme 1 Catalytic cycle proposed for the iodination reaction of compounds 1

We carried out the treatment of 1a with NaI (2.5 equiv) and $\mathrm{H}_{2} \mathrm{O}_{2}$ (5 equiv) using $\mathrm{SeCl}_{4}(20 \mathrm{~mol} \%)$ in water at $50{ }^{\circ} \mathrm{C}$ for $24 \mathrm{~h}$ (Table 1, entry 15) to conduct analyses of the reaction medium by electrospray ionization mass spectrometry (ESI-MS), employing positive (ESI+) and negative (ESI-) modes, aiming to identify transient species related to the catalytic cycle of Scheme 1, as well as to follow the transformation progress at 1, 3, 6, 12, and 24 hours. However, no transient species related to the catalytic cycle of Scheme 1 were detected.

In an attempt to provide some experimental support for the catalytic cycle shown in Scheme 1, we performed qualitative tests aiming to confirm the formation of molecular iodine in the reaction medium. ${ }^{16}$ Accordingly, we prepared aqueous solutions of $\mathrm{SeCl}_{4}(0.08 \mathrm{M})$ and of $\mathrm{NaI}(2 \mathrm{M})$. Then, by addition of $2.5 \mathrm{~mL}$ of $\mathrm{NaI}(2 \mathrm{M})$ to $5 \mathrm{~mL}$ of $\mathrm{SeCl}_{4}(0.08 \mathrm{M})$, both colorless solutions produced a brownish mixture, indicating a possible formation of molecular iodine; this conclusion was supported by addition of a solution of starch $(1 \% ; 5 \mathrm{~mL})$, which produced a black mixture. In addition, another test was performed, in which we prepared the brownish solution (as described above) and added a saturated solution of $\mathrm{Na}_{2} \mathrm{~S}_{2} \mathrm{O}_{3}(5 \mathrm{~mL})$ leading to a colorless aqueous solution presumably by reduction of molecular iodine back to iodide.

Aiming to expand the scope of the developed transformation (Table 2), we considered the use of $\mathrm{NaBr}$ and $\mathrm{NaCl}$ for the introduction of $\mathrm{Br}$ and $\mathrm{Cl}$ atoms, respectively, in aromatic and heteroaromatic compounds $\mathbf{1}$. Thus, we treated 1a with $\mathrm{NaBr}$ (2.5 equiv) and $\mathrm{H}_{2} \mathrm{O}_{2}$ (5 equiv) using $\mathrm{SeCl}_{4}(20$ $\mathrm{mol} \%$ ) in water at $50{ }^{\circ} \mathrm{C}$ for $24 \mathrm{~h}$ and obtained 1-(3,5-dibromo-4-hydroxyphenyl)ethanone (4) in 62\% yield (Scheme 2 ).

Allowing 1a to react with $\mathrm{NaCl}$ (2.5 equiv) and $\mathrm{H}_{2} \mathrm{O}_{2}$ (5 equiv) employing $\mathrm{SeCl}_{4}(20 \mathrm{~mol} \%)$ in water at $50{ }^{\circ} \mathrm{C}$ for $24 \mathrm{~h}$, 1-(3,5-dichloro-4-hydroxyphenyl)ethanone (5) was not ob-

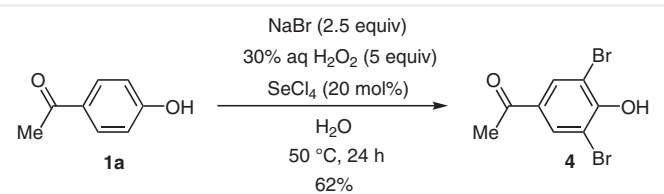

Scheme 2 Dibromination reaction of compound 1a

tained. Instead, the starting material 1a was partially recovered, and unidentified substances were produced according to GC/MS analysis. It is worth mentioning that, in the case of the reaction using $\mathrm{NaCl}$, the $\mathrm{pH}$ remained between 0 and 1 throughout the reaction (Scheme 3 ).

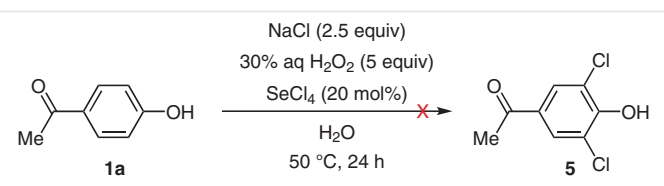

Scheme 3 Dichlorination reaction of compound 1 a

The structures proposed for compounds $\mathbf{2 a}-\mathbf{n}, \mathbf{3}$, and $\mathbf{4}$ are supported by their ${ }^{1} \mathrm{H}$ and ${ }^{13} \mathrm{C}$ NMR, IR, and mass spectra (see the Supporting Information).

In summary, a biomimetic iodofunctionalization of aromatic and heteroaromatic compounds has been developed that employs $\mathrm{NaI}$ as an inexpensive iodine source, $30 \% \mathrm{H}_{2} \mathrm{O}_{2}$ as a mild oxidizing agent, and $\mathrm{SeCl}_{4}$ as a commercially available catalyst, in water without a co-solvent, affording iodinated aromatic and heteroaromatic compounds in good isolated yields. The method can be considered an attractive alternative approach to prepare iodinated compounds, with potential applications in organic synthesis, medicinal chemistry, and medicine. In addition, the catalytic system developed presents potential for the bromination of aromatic and heteroaromatic compounds. In this sense, we intend to explore the bromination of aromatic and heteroaromatic substances and the results will be disclosed in due course.

\section{Funding Information}

This work was supported by the Fundação de Amparo à Pesquisa do Estado de São Paulo (São Paulo Research Foundation; FAPESP; Grant \#2017/21990-0). B.C.O.R. thanks the National Council for Scientific and Technological Development (CNPq) and G.P.P. thanks the Coordination for the Improvement of Higher Education Personnel (CAPES) for their fellowships.

\section{Supporting Information}

Supporting information for this article is available online at https://doi.org/10.1055/s-0039-1690337. 


\section{References and Notes}

(1) (a) Biffis, A.; Centomo, P.; Zotto, A. D.; Zecca, M. Chem. Rev. 2018, 118, 2249. (b) Chinchilla, R.; Nájera, C. Chem. Soc. Rev. 2011, 40, 5084. (c) Cordovilla, C.; Bartolomé, C.; Martínez-Ilarduya, J. M.; Espinet, P. ACS Catal. 2015, 5, 3040. (d) Maluenda, I.; Navarro, O. Molecules 2015, 20, 7528. (e) Ruiz-Castillo, P.; Buchwald, S. L. Chem. Rev. 2016, 116, 12564.

(2) (a) Capriati, V.; Perna, F. M.; Salomone, A. Dalton Trans. 2014, 14204. (b) Zhong, Z.; Wang, Z.-Y.; Ni, S.-F.; Dang, L.; Lee, H. K.; Peng, X.-S.; Wong, H. N. C. Org. Lett. 2019, 21, 700. (c) Boultwood, T.; Bull, J. A. Org. Lett. 2014, 16, 2740.

(3) (a) Ziegler, D. S.; Wei, B.; Knochel, P. Chem. Eur. J. 2019, 25, 2695. (b) Bao, R. L.-Y.; Zhao, R.; Shi, L. Chem. Commun. 2015, 51, 6884. (c) Barl, N. M.; Werner, V.; Sämann, C.; Knochel, P. Heterocycles 2014, 88, 827.

(4) (a) Spindler, B.; Kataeva, O.; Knölker, H.-J. J. Org. Chem. 2018, 83, 15136. (b) Zhang, Y.; Banwell, M. G. J. Org. Chem. 2017, 82, 9328. (c) Williams, S.; Jin, J.; Kan, S. B. J.; Li, M.; Gibson, L. J.; Paterson, I. Angew. Chem. Int. Ed. 2017, 56, 645. (d) Nguyen, M. H.; Imanishi, M.; Kurogi, T.; Smith, A. B. III. J. Am. Chem. Soc. 2016, 138, 3675. (e) Zhang, Z.; Xie, H.; Li, H.; Gao, L.; Song, Z. Org. Lett. 2015, 17, 4706 .

(5) (a) Jagadesan, P.; Schanze, K. S. Macromolecules 2019, 52, 3845. (b) Rodrigues, R. R.; Raminelli, C.; Péres, L. O. Eur. Polym. J. 2018, 106, 202. (c) Traina, C. A.; Bakus, R. C. II.; Bazan, G. C. J. Am. Chem. Soc. 2011, 133, 12600. (d) Jahnke, A. A.; Howe, G. W.; Seferos, D. S. Angew. Chem. Int. Ed. 2010, 49, 10140.

(6) (a) Mondal, S.; Raja, K.; Schweizer, U.; Mugesh, G. Angew. Chem. Int. Ed. 2016, 55, 7606. (b) Lavoie, S.; Brumley, D.; Alexander, T. S.; Jasmin, C.; Carranza, F. A.; Nelson, K.; Quave, C. L.; Kubanek, J. J. Org. Chem. 2017, 82, 4160. (c) Silva, E. J. G.; Bezerra-Souza, A.; Passero, L. F. D.; Laurenti, M. D.; Ferreira, G. M.; Fujii, D. G. V.; Trossini, G. H. G.; Raminelli, C. Future Med. Chem. 2018, 10, 2069.

(7) (a) Kortylewicz, Z. P.; Kimura, Y.; Inoue, K.; Mack, E.; Baranowska-Kortylewicz, J. J. Med. Chem. 2012, 55, 2649. (b) Zhao, L.; Zhu, J.; Cheng, Y.; Xiong, Z.; Tang, Y.; Guo, L.; Shi, X.; Zhao, J. ACS Appl. Mater. Interfaces 2015, 7, 19798. (c) Wang, C.; Jin, Q.; Yang, S.; Zhang, D.; Wang, Q.; Li, J.; Song, S.; Sun, Z.; Ni, Y.; Zhang, J.; Yin, Z. Mol. Pharmaceutics 2016, 13, 180.

(8) (a) Lusic, H.; Grinstaff, M. W. Chem. Rev. 2013, 113, 1641. (b) Lee, N.; Choi, S. H.; Hyeon, T. Adv. Mater. 2013, 25, 2641. (c) Attia, M. F.; Anton, N.; Chiper, M.; Akasov, R.; Anton, H.; Messaddeq, N.; Fournel, S.; Klymchenko, A. S.; Mély, Y.; Vandamme, T. F. ACS Nano 2014, 8, 10537. (d) Ding, Y.; Zhang, X.; Xu, Y.; Cheng, T.; Ou, H.; Li, Z.; An, Y.; Shen, W.; Liu, Y.; Shi, L. Polym. Chem. 2018, 9, 2926. (e) Gaikwad, H. K.; Tsvirkun, D.; Ben-Nun, Y.; Merquiol, E.; Popovtzer, R.; Blum, G. Nano Lett. 2018, 18, 1582.

(9) Küpper, F. C.; Feiters, M. C.; Olofsson, B.; Kaiho, T.; Yanagida, S.; Zimmermann, M. B.; Carpenter, L. J.; Luther, G. W. III.; Lu, Z.; Jonsson, M.; Kloo, L. Angew. Chem. Int. Ed. 2011, 50, 11598.

(10) (a) Leas, D. A.; Dong, Y.; Vennerstrom, J. L.; Stack, D. E. Org. Lett. 2017, 19, 2518. (b) Hofmann, D.; Hofmann, J.; Hofmann, L.-E.; Hofmann, L.; Heinrich, M. R. Org. Process Res. Dev. 2015, 19, 2075. (c) Trusova, M. E.; Krasnokutskaya, E. A.; Postnikov, P. S.; Choi, Y.; Chi, K.-W.; Filimonov, V. D. Synthesis 2011, 2154. (d) Zarchi, M. A. K.; Ebrahimi, N. J. Appl. Polym. Sci. 2011, 121, 2621.
(11) (a) Iida, K.; Ishida, S.; Watanabe, T.; Arai, T. J. Org. Chem. 2019, 84, 7411. (b) Tang, R.-J.; Milcent, T.; Crousse, B. J. Org. Chem. 2018, 83, 930. (c) Racys, D. T.; Sharif, S. A. I.; Pimlott, S. L.; Sutherland, A. J. Org. Chem. 2016, 81, 772. (d) Leboeuf, D.; Ciesielski, J.; Frontier, A. J. Synlett 2014, 25, 399. (e) Gallo, R. D. C.; Ferreira, I. M.; Casagrande, G. A.; Pizzuti, L.; Oliveira-Silva, D.; Raminelli, C. Tetrahedron Lett. 2012, 53, 5372. (f) Gallo, R. D. C.; Gebara, K. S.; Muzzi, R. M.; Raminelli, C. J. Braz. Chem. Soc. 2010, 21, 770. (g) Jereb, M.; Zupan, M.; Stavber, S. Chem. Commun. 2004, 2614. (h) Filimonov, V. D.; Semenischeva, N. I.; Krasnokutskaya, E. A.; Hwang, H. Y.; Chi, K.-W. Synthesis 2008, 401. (i) Prakash, G. K. S.; Mathew, T.; Hoole, D.; Esteves, P. M.; Wang, Q.; Rasul, R.; Olah, G. A. J. Am. Chem. Soc. 2004, 126, 15770. (j) Lulinski, P.; Kryska, A.; Sosnowski, M.; Skulski, L. Synthesis 2004, 441. (k) Barluenga, J. Pure Appl. Chem. 1999, 71, 431.

(12) (a) Alberto, E. E.; Muller, L. M.; Detty, M. R. Organometallics 2014, 33, 5571. (b) Abe, M.; You, Y.; Detty, M. R. Organometallics 2002, 21, 4546. (c) Francavilla, C.; Drake, M. D.; Bright, F. V.; Detty, M. R. J. Am. Chem. Soc. 2001, 123, 57. (d) Higgs, D. E.; Nelen, M. I.; Detty, M. R. Org. Lett. 2001, 3, 349. (e) Detty, M. R.; Zhou, F.; Friedman, A. E. J. Am. Chem. Soc. 1996, 118, 313. (f) Alberto, E. E.; Braga, A. L.; Detty, M. R. Tetrahedron 2012, 68, 10476. (g) Bennett, S. M.; Tang, Y.; McMaster, D.; Bright, F. V.; Detty, M. R. J. Org. Chem. 2008, 73, 6849. (h) Goodman, M. A.; Detty, M. R. Organometallics 2004, 23, 3016. (i) Drake, M. D.; Bright, F. V.; Detty, M. R. J. Am. Chem. Soc. 2003, 125, 12558. (j) Drake, M. D.; Bateman, M. A.; Detty, M. R. Organometallics 2003, 22, 4158.

(13) Bhuyan, B. J.; Mugesh, G. Inorg. Chem. 2008, 47, 6569.

(14) Selected examples of deiodination reactions catalyzed by selenium compounds: (a) Mondal, S.; Mugesh, G. Chem. Eur.J. 2019, 25, 1773. (b) Mondal, S.; Mugesh, G. Org. Biomol. Chem. 2016, 14, 9490. (c) Mondal, S.; Manna, D.; Mugesh, G. Angew. Chem. Int. Ed. 2015, 54, 9298. (d) Raja, K.; Mugesh, G. Angew. Chem. Int. Ed. 2015, 54, 7674.

(15) Preparation of Iodinated Compounds 2a-n and 3; General Procedure: To a solution of compound 1a-o $(2 \mathrm{mmol}$ in $2.5 \mathrm{~mL}$ of $\left.\mathrm{H}_{2} \mathrm{O}\right)$ under stirring at $50{ }^{\circ} \mathrm{C}$ was added a solution of $\mathrm{SeCl}_{4}(20$ $\mathrm{mol} \%$ in $5 \mathrm{~mL}$ of $\mathrm{H}_{2} \mathrm{O}$ ). Then, $2 \mathrm{M}$ aqueous solutions of $\mathrm{NaI}$ ( 5 or $2.5 \mathrm{mmol}$ ) and of $\mathrm{H}_{2} \mathrm{O}_{2}$ (10 or $5 \mathrm{mmol}$ ) were added alternately in small aliquots (every $5 \mathrm{~min}$ over a period of $50 \mathrm{~min}$ ) and the mixture was maintained under stirring at $50{ }^{\circ} \mathrm{C}$ for $24 \mathrm{~h}$. A saturated aqueous solution of $\mathrm{Na}_{2} \mathrm{~S}_{2} \mathrm{O}_{3}(10 \mathrm{~mL})$ was then added to the reaction, the mixture was extracted with ethyl acetate $(3 \times 20 \mathrm{~mL})$ and the organic phase was dried over $\mathrm{MgSO}_{4}$. After filtration, the solvent was evaporated under reduced pressure. The residue was purified by column chromatography on silica gel using an appropriate eluent, to afford the desired product $\mathbf{2 a}-\mathbf{n}$ and 3.

1-(4-Hydroxy-3,5-diiodophenyl)ethenone (2a): Yield: $483 \mathrm{mg}$ (62\%); off-white solid; $R_{f}=0.55\left(\mathrm{CH}_{2} \mathrm{Cl}_{2}\right) ; \mathrm{mp} 173{ }^{\circ} \mathrm{C}$ [lit.17 $173^{\circ} \mathrm{C}$. ${ }^{1} \mathrm{H}$ NMR $\left(300 \mathrm{MHz}\right.$, DMSO- $\left.d_{6}\right): \delta=8.26(\mathrm{~s}, 2 \mathrm{H}), 3.38(\mathrm{~s}$, $1 \mathrm{H}), 2.51(\mathrm{~s}, 3 \mathrm{H}) .{ }^{13} \mathrm{C}$ NMR $\left(75 \mathrm{MHz}\right.$, DMSO- $\left.d_{6}\right): \delta=194.7$, 159.8, 139.7, 132.8, 86.4, 26.6. IR (KBr): 3173, 1665, 1460, 1393, $1233 \mathrm{~cm}^{-1}$. MS (EI): $\mathrm{m} / \mathrm{z}(\%)=387.7$ (71.7), 372.7 (100.0), 217.8 (18.2), 91.0 (25.6), 43.0 (59.3).

(16) Vogel, A. I. In Vogel's Textbook of Quantitative Chemical Analysis, 5th ed; Longman Scientific \& Technical: Harlow, 1989.

(17) Baker, W.; Sansbury, H.; Simmonds, W. H. C. J. Soc. Chem. Ind. (London) 1943, 62, 193. 